\title{
Association between rs267196 and rs267201 of BMP6 gene and osteonecrosis among Sickle Cell Aneamia patients
}

\author{
Leila Chaouch ${ }^{\mathrm{a}}$, Miniar Kalai ${ }^{\mathrm{a}}$, Manel Ben Jbara ${ }^{\mathrm{a}}$, Arij Ben Chaabene ${ }^{\mathrm{b}}$, Imen Darragi ${ }^{\mathrm{a}}$, Dorra Chaouachia ${ }^{\mathrm{a}}$, Fethi Malloulia, \\ Raouf Hafsiac, Abderraouf Ghanem ${ }^{\mathrm{d}}$, Salem Abbes ${ }^{\mathrm{a}}$
}

\begin{abstract}
Aims. The skeletal manifestations of sickle cell disease are the result of changes in bone and bone marrow caused by chronic tissue hypoxia that is exacerbated by episodic occlusion of the microcirculation by the abnormal sickle cells. Furthermore, the occurrence of osteonecrosis is under the control of some modifier gene. BMP6 (Bone morphogenetic protein) has been reported as associated with osteonecrosis in sickle cell anemia (SCA). Herein, we intend to study the impact of rs267196, rs267201, rs408505 and rs449853 of BMP6 gene in the occurrence of osteonecrosis among sickle cell patients in Tunisia.

Methods. Our study involved 100 SCA patients among whom 19 have osteonecrosis of the head of the femur. The latter polymorphisms of BMP6 gene were analyzed for all subjects by PCR/sequencing. To test for trait association with the candidate SNPs, genotype and allele frequencies between cases (osteonecrosis group) and controls (non-osteonecrosis group) were compared using Pearson's chi_square test with a significance threshold of $P<0.05$ (compare 2, version 1.02). Results. Our findings showed that the patients carried genotype TA of rs 267196 and genotype AG of rs 267201 present a high risk factor for developing osteonecrosis $R R=1.317$ and $R R=1.3$ respectively. The results showed a significant association between the alleles $A$ of $r s 267196$ and $G$ of rs 267201 and osteonecrosis $P=0.0023 ; R R=2.42$ and $P=0.041$; $\mathrm{RR}=2.24$ respectively. Interestingly, SCA patients with the combined genotype TA/AG were found to be at higher risk of developing osteonecrosis $(P=0.009)$. As for rs408505 and rs449853 of BMP6 gene no significant association was found among SCA patients.
\end{abstract}

Key words: Sickle Cell Anemia, BMP6 polymorphisms, osteonecrosis

Received: March 19, 2013; Accepted with revision: October 15, 2013; Available online: November 13, 2013 http://dx.doi.org/10.5507/bp.2013.080

aLaboratory of Molecular and Cellular Hematology, Tunis El Manar University, Pasteur Institute of Tunis, Tunis, Tunisia
'Department of Clinical Biology, Salah Azaiz Institute of Cancer, Tunis El Manar University, Tunis, Tunisia
'Department of Clinical Hematology, Tunis El Manar University, Hospital Aziza Othmana, Tunis, Tunisia
'Department of Biochemistry, Tunis El Manar University, Hospital de Traumatologie et des Grands Brulés, Tunis, Tunisia
Corresponding author: Leila Chaouch, e-mail: Leila.chaouch@gmail.com

\section{INTRODUCTION}

SCA is a single-gene mutation genetic disease caused by change of Glu6Val at the hemoglobin beta chain gene and characterized by high variable clinical complications ${ }^{1}$. The skeletal manifestations of sickle cell disease are the result of changes in bone and bone marrow caused by the chronic tissue hypoxia that is exacerbated by episodic occlusion of the microcirculation by the abnormal sickle cells. Furthermore, the occurrence of osteonecrosis is under the control of some modifier gene. BMP6 (Bone morphogenetic protein) has been reported as associated with osteonecrosis in sickle cell anemia (SCA) $\left(\right.$ ref. $\left.^{2}\right)$. Bone morphogenetic proteins (BMPs) are members of the TGF-beta superfamily of molecules. They are multifunctional cytokines involved in many aspects of tissue development and morphogenesis. BMP6 is involved in inflammatory processes and is important for bone formation and, in association with parathyroid hormone (PTH) and vitamin D, appears to be involved in inducing bone development by human bone marrow-derived mesenchymal stem cells ${ }^{3}$. BMP6 promotes osteoblast differentiation from mesenchymal stem cells ${ }^{4-5}$ studied the role of BMP6 in cartilage homeostasis; they discovered an essential involvement of this gene in the repair/maintenance of human articular cartilage. In sickle cell osteonecrosis, the progressive degeneration of the bone eventually led to its collapse and destruction of articular cartilage, supporting a role of BMP6 in the pathogenesis of this complication. Indeed, Baldwin et al. ${ }^{6}$ have reported the role of $\mathrm{rs} 267196$, rs267201 and rs449853 in the occurrence of osteonecrosis in sickle cell disease.

Herein, we aimed to explore the implication of four known polymorphisms of BMP6: rs408505, rs449853, rs267201 and rs267196 in osteonecrosis among SCA patients.

\section{MATERIAL AND METHODS}

\section{Material}

100 sickle cell patients were involved in this study. Patients were selected on the basis of homozygosity for

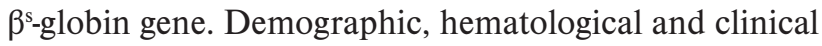
data of subjects studied are summarized in Table 1. 


\section{METHODS}

\section{Clinical events}

Data and clinical events were taken from the patient's history via search of the clinical registry with radiologically documented osteonecrosis. Patients chosen in this study have osteonecrosis of the head of the femur.

\section{Laboratory methods}

Diagnosis of sickle cell patient is performed using cation-exchange high performance liquid chromatography (HPLC) (D10 Biorad) and further confirmation by means of molecular diagnosis by restriction fragment length polymorphism (RFLP) using DdeI as previously described by Romana $2000^{7}$. Biochemical data were averaged for each patient in steady state (at least three values). We determined total and fetal hemoglobin ( $\mathrm{HbF}$ ) concentrations (D10, Biorad), and reticulocyte count and other hematologic parameters using (ABX pentra $60 \mathrm{c}+$ ).

\section{Genotyping of BMP6 polymorphisms}

Genomic DNA was isolated from white blood cells of total blood using standard method (phenol/chloroform). A polymerase chain reaction (PCR) was performed using 4 couple of primers as described in Table 2. Polymerase chain reaction was performed in $25 \mu \mathrm{L}$ reaction volumes containing $100 \mathrm{ng}$ of genomic DNA, $0.2 \mathrm{mmol} / \mathrm{L}$ of each dNTP, $50 \mathrm{mmol} / \mathrm{L} \mathrm{KCl}, 15 \mathrm{mmol} / \mathrm{L}$ Tris-HCl PH 8.0, $2.5 \mathrm{mmol} / \mathrm{L} \mathrm{MgCl}_{2}$, $0.5 \mathrm{U}$ Amplitaq polymerase (Invitrogen life technologies, Carlsbad, CA, USA), and 10 pmol of each forward and reverse primers. The PCR cycling conditions included an initial denaturation of 10 min at $94{ }^{\circ} \mathrm{C}$ followed by 35 cycles of $94{ }^{\circ} \mathrm{C}$ for $60 \mathrm{~s}$, annealing at $59{ }^{\circ} \mathrm{C}$ for $60 \mathrm{~s}$, and extension at $72{ }^{\circ} \mathrm{C}$ for $1 \mathrm{~min}$. The run was ended by a final extension at $72{ }^{\circ} \mathrm{C}$ for $10 \mathrm{~min}$.

PCR products were then purified and doubly sequenced (forward and reverse) by ABI PRISM Big Dye Terminator on ready reaction kit (Applied Biosystems, Foster City, CA, USA) and an ABI 310 DNA sequencer (PEApplied Biosystems, Foster City, USA).

\section{Statistical analysis}

The demographic and hematologic data were normally distributed. The Hardy-Weinberg equilibrium was tested using the software package Arlequin (version 3.01). Genetic differences between cases and controls were evaluated applying tests to genotypic or allelic contingency tables (Compare 2, version 1.02). We used Fisher's exact test and chi-squared tests where appropriate.

\section{RESULTS}

The sample of patients was divided into two groups according to the presence or absence of osteonecrosis. Hematologic data such as hemoglobin and other parameters suggested similar hemolytic rates in these groups (Table 1). The two groups of patients stratified accordingly to the occurrence of osteonecrosis were compared for age, sex ratio and hematological data including $\mathrm{HbF}$. No significant association was found.

For each polymorphism the samples were found to be in Hardy-Weinberg equilibrium. As for BMP6 polymorphisms, the distribution of genotypes and alleles was analyzed for all patients (Table 3 ). Indeed, for the polymorphisms rs408505 and rs449853 the repartition of genotypes and alleles between the two groups of patients showed no significant association. Further, the analysis of genetic profile of rs267196 showed that the major genotype in SCA patients without osteonecrosis is the normal TT (50.62\%). Although it is the TA (63.16\%) among SCA with osteonecrosis. As for rs267201, our results showed that the major genotype in SCA patients without osteonecrosis was the normal AA (53.09\%) and AG (57.9\%) in SCA patients with osteonecrosis. The distribution of genotypes between SCA patients according to the presence or absence of osteonecrosis revealed that patients carried genotype TA of rs267196 and genotype AG of rs267201 present a risk factor for developing osteonecrosis $\mathrm{OR}=1.317$ and $\mathrm{OR}=1.3$ respectively (Table 3 ). The analysis of allelic distribution showed the association of variant A of rs267196 and variant G of rs267201 with the

Table 1. Hematological, demographic and clinical data of studied population.

\begin{tabular}{lccc}
\hline & $\begin{array}{c}\text { SCA patients } \\
\text { Without osteonecrosis }\end{array}$ & $\begin{array}{c}\text { SCA patients } \\
\text { With osteonecrosis }\end{array}$ & $P$ \\
\hline Age & $\mathrm{N}=81$ & $\mathrm{~N}=19$ & 1 \\
Sex ratio & $30 \pm 5$ & $30 \pm 5$ & 0.120 \\
$\mathrm{Hb}(\mathrm{g} / \mathrm{dl})$ & $41 / 59$ & $9 / 10$ & 0.530 \\
$\mathrm{RBC}\left(10^{12} \mathrm{~L}\right)$ & 9.7 & 9.3 & 0.080 \\
$\mathrm{MCV}(\mathrm{fl})$ & $3.29 \pm 0.9$ & $2.89 \pm 1.02$ & 0.095 \\
$\mathrm{MCH}(\mathrm{pg})$ & $79.7 \pm 0.9$ & $74.2 \pm 1.3$ & 0.075 \\
$\mathrm{RDW}(\%)$ & $34.9 \pm 2.1$ & $35.7 \pm 1.02$ & 0.120 \\
$\mathrm{HbA}$ & $4.83 \pm 0.5$ & $5.29 \pm 1.02$ & 1 \\
$\mathrm{HbS}(\%)$ & 0 & 0 & 1 \\
$\mathrm{HbF}(\%)$ & $86 \pm 0.3$ & $86.4 \pm 0.4$ & 0.900 \\
$\mathrm{HbA} 2$ & $11 \pm 0.1$ & $10.6 \pm 0.3$ & 1 \\
\hline
\end{tabular}

Hb: hemoglobin, RBC: red blood cell, MCV: mean corpuscular volume, MCH: mean corpuscular hemoglobin and RDW: red blood distribution. 
risk of developing osteonecrosis (Table 3). Interestingly, the stratification of genotypes found using logistic regression according to the presence or absence of osteonecrosis revealed the association of both genotypes TA of rs267196 and AG of rs267201 with osteonecrosis and thus appears to present a risk factor for the occurrence of osteonecrosis $(P=0.009)$ (Table 4$)$. The repartition of genetic profile according to hematological parameters showed no significant differences between the groups with risk genotype and whose with normal genotype (Table 5).

\section{DISCUSSION}

Osteonecrosis is a common sequela of sickle cell disease; studies suggest that some modifier genes are found to be associated with this complication ${ }^{2}$. Genetic association studies, which attempt to link gene polymorphisms with selected complications, highlighted some variants
Table 2. Primer sequences.

\begin{tabular}{cc}
\hline rs & \multicolumn{1}{c}{ Primers } \\
\hline \multirow{2}{*}{ rs267196 } & F 1: 5'-GGCAGGCATGTTATCCTTGAGA-3' \\
& R 1: 5'-AGAAGCATTCTTGGGGTGTCTG-3' \\
& F 2: 5'-GTTGCCTTGCTTGGTTGCTCTA-3' \\
rs267201 & R 2: 5'-ACATTGGGTCCCGATCTTGTTT-3' \\
& Fs 3: 5'-GGCTATTTTTGGAATTGTGCTGTC-3' \\
& R3: 5'-TGGTAAGAAATGGAGGCTGAAAAA-3' \\
& F 4: 5'-GGTTTTGATGAATGGGCTGAAG-3' \\
rs449853 & R 4: 5'-TCTGACTCATGGGTCTGGGATT-3' \\
\hline
\end{tabular}

Table 3. Genotypic and allelic distribution of studied BMP6 polymorphisms.

\begin{tabular}{|c|c|c|c|c|}
\hline & \multicolumn{2}{|c|}{ Osteonecrosis } & \multirow[b]{2}{*}{$P$} & \multirow{2}{*}{$\begin{array}{c}\mathrm{RR} \\
\text { CI95\% }\end{array}$} \\
\hline & $\begin{array}{c}\text { Absence } \\
\mathrm{N}=81\end{array}$ & $\begin{array}{c}\text { Presence } \\
\mathrm{N}=19\end{array}$ & & \\
\hline \multicolumn{5}{|c|}{ rs 408505} \\
\hline $\mathrm{C}$ & 0.519 & 0.553 & $1 *$ & - \\
\hline $\mathrm{T}$ & 0.481 & 0.447 & NS & - \\
\hline $\mathrm{CC}$ & 22 & 5 & $1^{*}$ & - \\
\hline $\mathrm{CT}$ & 40 & 11 & NS & - \\
\hline TT & 19 & 3 & NS & - \\
\hline \multicolumn{5}{|c|}{ rs 449853} \\
\hline A & 0.420 & 0.526 & $1 *$ & - \\
\hline G & 0.580 & 0.474 & NS & - \\
\hline AA & 18 & 5 & $1^{*}$ & - \\
\hline $\mathrm{AG}$ & 32 & 10 & NS & - \\
\hline GG & 31 & 4 & NS & - \\
\hline \multicolumn{5}{|c|}{ rs 267196} \\
\hline $\mathrm{T}$ & 0.685 & 0.474 & $1 *$ & - \\
\hline A & 0.315 & 0.526 & 0.0023 & $\begin{array}{c}2.42 \\
(1.105-5.286)\end{array}$ \\
\hline $\mathrm{TT}$ & 41 & 3 & $1 *$ & - \\
\hline TA & 29 & 12 & 0.009 & $\begin{array}{c}1.317 \\
(1.07-1.63)\end{array}$ \\
\hline AA & 11 & 4 & NS & - \\
\hline \multicolumn{5}{|c|}{ rs 267201} \\
\hline A & 0.691 & 0.5 & $1 *$ & - \\
\hline G & 0.309 & 0.5 & 0.041 & $\begin{array}{c}2.24 \\
(1.021-4.335)\end{array}$ \\
\hline AA & 43 & 4 & $1^{*}$ & - \\
\hline $\mathrm{AG}$ & 26 & 11 & 0.02 & $\begin{array}{c}1.3 \\
(1.04-1.63)\end{array}$ \\
\hline GG & 12 & 4 & NS & - \\
\hline
\end{tabular}

$P$ : index of significance.

NS: Non-Significant.

RR: Relative-Risk.

CI: confidence interval.

$1 *$ : reference group. 
Table 4. Repartition of combinated genotypes of rs267196/rs267201 according to presence or not of osteonecrosis.

\begin{tabular}{|c|c|c|c|c|c|}
\hline \multirow[b]{2}{*}{ Combinated genotypes } & & \multicolumn{2}{|c|}{ Osteonecrosis } & \multirow[b]{2}{*}{$P$} & \multirow[b]{2}{*}{$\begin{array}{c}\text { RR } \\
\text { CI 95\% }\end{array}$} \\
\hline & & $\begin{array}{c}\text { Presence } \\
\mathrm{N}=19\end{array}$ & $\begin{array}{c}\text { Absence } \\
\mathrm{N}=81\end{array}$ & & \\
\hline \multirow[t]{7}{*}{ rs267196/rs267201 } & TT/AA & 3 & 39 & $1^{*}$ & - \\
\hline & TA/AA & 1 & 3 & NS & - \\
\hline & $\mathrm{TT} / \mathrm{GG}$ & 0 & 2 & NS & - \\
\hline & TA/AG & 11 & 25 & 0.009 & $\begin{array}{c}1.337 \\
(1.06-1.69)\end{array}$ \\
\hline & TA/GG & 0 & 2 & NS & - \\
\hline & $\mathrm{AA} / \mathrm{AG}$ & 0 & 2 & NS & - \\
\hline & $\mathrm{AA} / \mathrm{GG}$ & 4 & 8 & NS & - \\
\hline
\end{tabular}

$P$ : index of significance.

NS: Non-Significant.

RR: Relative-Risk.

$1^{*}$ : reference group.

Table 5. Repartition of genetic profile of rs267196/rs267201 according to hematological parameters.

\begin{tabular}{lccccccccc}
\hline & \multicolumn{3}{c}{ Rs 267196 } & & & Rs 267201 & \multicolumn{3}{c}{ rs267196/rs267201 } \\
\hline Genotypes & TT* & TA & $P$ & AA* & AG & $P$ & TT/AA* & TA/AG & $P$ \\
\hline $\mathrm{Hb}(\mathrm{g} / \mathrm{dL})$ & 9.6 & 9.1 & 0.620 & 9.7 & 9.2 & 0.530 & 9.7 & 9.3 & 0.530 \\
$\mathrm{RBC}\left(10^{12} \mathrm{~L}\right)$ & $3.2 \pm 0.5$ & $2.8 \pm 0.8$ & 0.100 & $3.29 \pm 0.9$ & $2.79 \pm 0.8$ & 0.080 & $3.2 \pm 1.02$ & $2.79 \pm 0.9$ & 0.080 \\
$\mathrm{MCV}(\mathrm{fl})$ & $79.5 \pm 0.7$ & $74.7 \pm 0.9$ & 0.095 & $79.7 \pm 0.9$ & $75 \pm 0.9$ & 0.095 & $79.6 \pm 1.3$ & $75.7 \pm 0.9$ & 0.095 \\
$\mathrm{MCH}(\mathrm{pg})$ & $34.9 \pm 2.1$ & $35.9 \pm 2.1$ & 0.075 & $34.9 \pm 2.1$ & $35 \pm 2$ & 0.075 & $34.9 \pm 2.1$ & $35.4 \pm 2.1$ & 0.075 \\
$\mathrm{RDW}(\%)$ & $4.83 \pm 0.5$ & $5.23 \pm 0.5$ & 0.120 & $4.83 \pm 0.5$ & $5 \pm 0.2$ & 0.120 & $4.83 \pm 0.5$ & $5.16 \pm 0.7$ & 0.120 \\
\hline
\end{tabular}

$P$ : index of significance.

*: reference group.

of candidate gene. We examined the association of single nucleotide polymorphisms (SNPs) in candidate gene of bone metabolism with osteonecrosis in patients with SCA namely BMP6. This gene is important in bone morphology. BMP-6 was also shown to be associated with other vascular complications in SCD such as priapism ${ }^{8}$ and stroke $^{9}$, suggesting a common underlying molecular basis for these vascular complications.

In the current study, 4 SNPs in BMP6 were genotyped, and significant associations with osteonecrosis were observed with 2 SNPs namely: rs267196 and rs267201. As for rs408505 and rs449853 of BMP6 gene, no significant association was found among SCA patients. Our findings show that the patients who carried genotype TA of rs267196 and genotype AG of rs267201 present a high risk factor for developing osteonecrosis $\mathrm{RR}=1.317$ and $\mathrm{RR}=1.3$ respectively. Our results showed a significant association between the alleles A of rs267196 and $\mathrm{G}$ of rs267201 and osteonecrosis $P=0.0023$; $\mathrm{RR}=2.42$ and $P=0.041 ; \mathrm{RR}=2.24$ respectively. Interestingly, SCA patients with the combined genotype TA/AG were found to be at higher risk of developing osteonecrosis $(P=0.009)$. Only one study has identified the latter polymorphisms as associated with osteonecrosis ${ }^{6}$. Whereas Ulug et al. ${ }^{10}$ found no association between rs 267196 and avascular necrosis among SCA patients. Two studies have described the implication of
BMP6 polymorphisms in patients with sickle cell disease including SS, $\mathrm{S} \beta^{+}, \mathrm{S} \beta^{0}$ and $\mathrm{SC}$. By cons, in our study we focused on SS patients. The mechanisms by which rs267196 and rs267201 in BMP6 gene predispose sickle cell patients to osteonecrosis complication are unknown.

Elucidating the genetic basis for the development of sickle cell osteonecrosis may provide new insight into the pathogenesis in SCA patients and hence provide treatement options, which are still limited. As for BMP6, regulating the activity of the TGF- $\beta$ pathway to modulate its effects on bone may be possible ${ }^{11}$. Ultimately, rs267196 and rs267201 of BMP6 may be considered as a reliable biomarker for predicting at an early age, patients at high risk for osteonecrosis, and thus allow earlier and more effective therapeutic intervention.

\section{ABBREVIATIONS}

BMP6, bone morphogenetic protein6; CI, confidence interval; OR, odds ratio; $P$, index of significance; RR, relative risk; SCA, Sickle Cell Anemia. 


\section{ACKNOWLEDGEMENT}

Authorships contributions: LC: manuscript writing, study design, data interpretation; MK: data collection, literature search; MBJ: literature search; ABC: statistical analysis; ID, DC: data collection; FM, RH: data interpretation; AG, SA: data analysis.

Conflict of interest statement: None declared.

\section{REFERENCES}

1. West MS, Wethers D, Smith J, Steinberg M. Laboratory profile of sickle cell disease: across-sectional analysis. The Cooperative Study of Sickle Cell Disease. J Clin Epidemiol 1992;45:893-909.

2. Driss A, Asare KO, Hibbert JM, Gee BE, Adamkiewicz TV, Stiles JK. Cell Disease in the Post Genomic Era: A Monogenic Disease with a Polygenic Phenotype. Genomics insights 2009;2:23-48.

3. Rosendahl A, Pardali E, Speletas M, Ten Dijke P, Heldin CH, Sideras P. Activation of bone morphogenetic protein/Smad signaling in bronchial epithelial cells during airway inflammation. Am J Respir Cell Mol Biol 2002;27:160-9.

4. Lavery K, Swain P, Falb D, Alaoui-Ismaili MH. BMP-2/4 and BMP-6/7 differentially utilize cell surface receptors to induce osteoblastic differentiation of human bone marrow-derived mesenchymal stem cells. J Biol Chem 2008;283:20948-58.
5. Bobacz K, Gruber R, Soleiman A, Erlacher L, Smolen JS, Graninger WB. Expression of bone morphogenetic protein 6 in healthy and osteoarthritic human articular chondrocytes and stimulation of matrix synthesis in vitro. Arthrithis Rheum 2003;48(9):2501-08.

6. Baldwin C, Nolan VG, Wyszynski DF, Ma QL, Sebastiani P, Embury SH, Bisbee A, Farrell J, Farrer L, Steinberg MH. Association of klotho, bone morphogenic protein 6 , and annexin A2 polymorphisms with sickle cell ostéonécroses. Blood journal 2005;106:372-5.

7. Romana M, Keclard L, Froger A, Lavocat E, Saint-Martin C, Berchel C, Mérault EG. Diverse genetic mechanisms operate to generate atypical bS haplotypes in the population of Guadeloupe. Hemoglobin 2000;24:77-87.

8. Nolan VG, Baldwin C, Ma Q, Wyszynski DF, Amirault Y, Farrell J, Bisbee A, Embury SH, Farrer LA, Steinberg MH. Association of single nucleotide polymorphisms in klotho with priapism in sickle cell anaemia. Br J Haematol 2005;128:266-72.

9. Sharan K, Surrey S, Ballas S, Borowski M, Devoto M, Wang KF, Sandler E, Keller M. Association of T-786C eNOS gene polymorphism with increased susceptibility to acute chest syndrome in females with sickle cell disease. Br J Haematol 2004;124:240-3.

10. Ulug P, Vasavda N, Awogbade M Juliette Cunningham, Stephan Menzel, Swee Lay Thein. Association of sickle avascular necrosis with bone morphogenic protein 6. Ann Hematol 2009;88:803-5.

11. Callahan JF, Burgess JL, Fornwald JA, Gaster LM, Harling JD, Harrington FP, Heer J, Kwon C, Lehr R, Mathur A, Olson BA, Weinstock J, Laping NJ. Identification of novel inhibitors of the transforming growth factor- $\beta 1$ (TGF- $\beta 1$ ) type 1 receptor (ALK5). J Med Chem 2002:45:999-1001. 